\title{
EDUCATIONAL REFORMS IN NIGERIA: THE KADUNA STATE TEACHERS' COMPETENCY TEST
}

\author{
*Aina, J. K. \\ *School of science and mathematics education, University of the Western Cape, South Africa, Bellville, Western Cape \\ *Phone: +27745590594; +2348032304024*Email: physicseducation68@gmail.com
}

\begin{abstract}
This paper critically looked at the crisis generated by the teachers' competency test in the Kaduna state. Which agitates for the reform of the educational sector in Nigeria. The article strongly supported the need for such reforms nevertheless, faulted the procedural executions which encompassed the Kaduna state Teachers' Competency Test on the basis of some fundamental issues. The main issue of lack of standard in Nigeria education system was a concern for this paper. This paper reviewed some of the problems in the education system that should have been the crux of the reform. The teacher is an important variable that influences the learnedness of a nations citizenry. There are several skills which qualify a person as a teacher. The competency of a teacher can be characterized by the ability to learn, assimilate, understand and impact an acquired skill or knowledge following predefined standards and methods. This requires a carefully planned investigation using tactical approaches, if the competency of a teacher is to be accessed. This paper argued that for a reform in the educational sector to enhance sustainable development, there must be good governance and a populace free of corruption within and outside the education system. The article suggested some areas where the Nigerian education requires reform such as teacher education, teachers' condition of service and the school curricula visà-vis the Kaduna state teachers' competency test.
\end{abstract}

Keywords: competency test, curricula, education reform, sustainable development, teacher education.

LICENSE: This work by Open Journals Nigeria is licensed and published under the Creative Commons Attribution License 4.0 International License, which permits unrestricted use, distribution, and reproduction in any medium, provided this article is duly cited.

COPYRIGHT: The Author(s) completely retain the copyright of this published article.

OPEN ACCESS: The Author(s) approves that this article remains permanently online in the open access (OA) mode.

QA: This Article is published in line with "COPE (Committee on Publication Ethics) and PIE (Publication Integrity \& Ethics)". 


\section{INTRODUCTION}

Reform is useful and desirable in every sector of human lives. However, reform is only required when the existing system has failed or obsolete. There could be reform in any area of a country's status which may include: political, economic, social, cultural or educational reform etc. Therefore, the issue of reform in Nigeria education system is not peculiar. Advanced nations like Finland, Singapore, and the United States continually reform their education system (Zinth, 2014; Brenneman, 2014; Christie, 2014). Literature shows that developing countries like India and Qatar similarly had times of reform in their educational system (Srivastava \& Srivastava, 2017, Nasser et al., 2014). A Reform starts with the identification of a problem, which is further studied, analysed, and evaluated (Omosewo, 2008). Thus, the journey to any sustainable and worthwhile reform is long. In other to identify the problem, there may be the need for surveying and conducting series of test: Aptitude, Achievement, and Competency test as the case demanded. The instrument for the survey and test must be constructed by the experts within the field to ensure reliability and validity. (Flippo \& Foster, 1984).

\section{THE KADUNA STATE SAGA}

Lots of fuss about the competency test conducted for the teachers in Kaduna state has gone viral in the recent time. The state government is said to be reforming the education system in the state. Which led to a conducted test for the teachers in the primary schools. The result indicates that over twenty-one thousand teachers failed the test as reported by the state government. The government claimed that these teachers were not qualified. It should be noted that the government has a right to initiate teachers reform if need be. However, there are fundamental issues that reqiured critical examination before the evaluation of a teacher as in this case. These includes:

1. What qualifies a person to be a teacher?

2. Who coordinated and constructed the instrument for the evaluation of a teacher?

3. Who analysed, evaluated, and interpreted the results?

According to Zuzovsky (2003), formal education, experience, subject matter knowledge, pedagogy skill, duration of training, and professional development are aspects that qualify someone to be a teacher. The test conducted in the Kaduna case was on the subject matter knowledge, and this will be inadequate for evaluating the competency of a teacher. A more emcompasing test proceedure was not clearly reflected in the test.

Profound assessments which include a classroom performance assessment/pedagogy assessment were not clearly accessed. Performance assessments which measures what a teacher actually does in the classroom is very vital to evaluating a teachers' competence in teacher education (Darling-Hammond, 2010). A competency test for teachers is a test developed to measure the minimum knowledge and skills required for adequate performance in the classroom (Flippo \& Foster, 1984).

Teacher competency testing in Singapore is conducted through a well encompassed test model for teaching. This model according to Steiner (2010) consists principally of nurturing the whole child, cultivating knowledge, winning hearts and minds, working with others, and knowing self and others. Competency tests are used in conjunction with the achievement of performance outcomes to evaluate, track career, promote, and pay teachers in Singapore (Steiner, 2010). 
The pass mark for the test put at $75 \%$ is a little bit high. It implies any mark below this is fail. The grading system of the Nigerian colleges of education which is responsible for the training of the primary school teacher is not as high as this. The table below is the college of education grading system in Nigeria. The test in Kaduna may not adopt the NCCE grading system but could modify it by making the pass mark for the test to be $55 \%$ which would correspond to the merit of the NCCE grading system.

Table 1: NCCE student grading system

\begin{tabular}{llll}
\hline S/n & Grades & Interpretation (\%) & Remark \\
\hline 1 & A & $75-100$ & Distinction \\
2 & B & $65-74$ & Credit \\
3 & C & $55-64$ & Merit \\
4 & D & $45-49$ & Pass \\
5 & E & $40-44$ & Low Pass \\
6 & F & $0-39$ & Fail \\
\hline
\end{tabular}

Source: NCCE (2008)

In the light of the above, the ongoing education reform in Kaduna state is good but has some significant problems discussed below. These problems might not be peculiar to this state alone it may be a representation of what happens in many other states where the so-called reform had taken place.

First and foremost, many primary school pupils in Kaduna sits on the floor to learn because there is not enough furniture for these pupils. Similarly, there is inadequate furniture for teachers and other teaching aids. The reform, in this case, should start from the assessment of infrastructure and other learning resources besides the teacher. Akindutire and Ekundayo, (2012) noted that no programme, no matter how well planned, can succeed if adequate infrastructural facilities are not available for its implementation. The fundamental question should have been: Are there enough classrooms, furniture and teaching aids for the pupils to be taught by their teachers? A state may have the best teachers, but once these facilities are not adequate, the problem of learning is not yet solved.

It is good to reform the teacher, but it would have been better to reform the teacher education programme at the same time. In this case, the reform is atomistic instead of being holistic which would have offered a better realistic solution to the teacher's problem.

The decision to terminate the appointment of these teachers also might not be in the spirit of the reform. The government did not consider what will happen to the economy if over 20, 000 employees lose their job at once. If indeed were to be a well-planned reform, there should have being better options than the sudden termination of the teachers' appointment.

Finally, the reform process in education should be the responsibility of seasoned education experts. It will be mediocracy if education experts are made to be responsible for the reform in the health sector where seasoned health professionals are relegated to the background following political will. The critical skill professionals in any nations 
educational reform as in this case should strictly be seasoned experts in education without overhead political influences.

Given the challenges as discussed above, the paper will now elucidate appropriate reform measures in the nations education that is genuinely required by Nigeria. It is evident that Nigeria education has lots of problems which affects the teaching and learning process, especially the nation's economy. Therefore, education reform in Nigeria, which would engender sustainable development must consider some fundamental issues. Sustainable development is a development that meets the needs of the present without compromising the ability of future generations to meet their own needs (UNESCO, 2012). The reform by the Government of Kaduna state may not actually meet the needs of the present as over 21,000 teachers lost their jobs, thereby creating more challenges to the problem of unemployment.

\section{THE FUNDAMENTAL ISSUES IN THE NIGERIAN EDUCATION REFORM}

Reform is a long journey that starts with the identification of problems. It is clear that there are problems in the nation's education sector. It is evident in the academic performance of students in all level of education and output of schools at all levels (Idakwoji, 2016). Okemakinde, Adewuyi, and Alabi (2013) noted that there had been a decline in the quality of candidates admitted into the tertiary institutions as a result of the weak output of both the primary and the secondary levels.

The first fundamental issue is the lack of standards. According to Nasser et al. (2014), standards-based reform is the key to school reform principle. Therefore, for a sustainable reform, the starting point is to set standards for our education. According to Libman, (2012), most education reforms have emphasized the importance of establishing national standards for student achievement, for the quality of teaching, and for the effectiveness of curricula for schools and teacher training institutions. There are two un-official programmes practiced by some colleges of education called Re-run and Amnesty which are not found anywhere in the NCCE minimum standard. The programmes are used to assist poor students towards graduation or promotion to the next academic level. The abuse of the programmes confirmed the submission of Libman. Many poor students explored these programmes to obtain their National Certificate in Education (NCE) when they did not merit the certificate. Most of these NCE holders are teaching in our schools today. The question is: how would these teachers be effective? Where there are primary, secondary and higher education; there must be strict standards to be followed at these three levels with enforcement of compliances starting from the Teachers Training Schools. Floating standards gives rise to programmes like the Re-run and Amnesty in the college of education explained above. The country must reform its standards and enforce these standards ensuring strict compliance at all levels from the onset. Schools, Colleges, and Universities are established and managed as pleased by the states, corporate bodies and individuals attimes, even without standard acreditation. This is the beginning of the problem, and the reform must start here.

There are cries everywhere that the teachers in Nigerian schools are not competent. It is a justifiable cry as it occurred in Kaduna state as it is a well-established fact that a teacher is a school variable that influences students in various ways (Darling-Hammond, 2000; Boyd, Lankford, Loeb, Rockoff \& Wychoff, 2008; Palardy \& Rumberger, 2008). However, not many people focus on the processes that produces these teachers. Many of our Colleges of Education and other teacher training institutions are not doing well (Akinbote, 2007; Aina, 2015). There are no specific 
standards and compliance to standards as lecturers do whatever they please. Before the start of any semester examination, many lecturers in Colleges of Education already have a list of students' they must assist to pass the set examination. Most of these students eventually fails the exams, but their scores are adjusted to pass marks due to powerful influences within and outside the colleges. Some Provosts and Registrars are vital players in the academic failure of these colleges. Though unofficially documented, some Colleges of Education awards certificate to students who have not passed the prescribed exams, some admits unqualified students and some appointes lecturers who had no teaching qualifications and experience. The eventual result may resemble the outcome of the Kaduna state teacher's competency test. Recent careful observation shows that the number of private Colleges of Education in a particular state is growing at an exponential rate over time. The state government collects money from the proprietors, and the National Commission for Colleges of Education allows them to operate without strictly compliance to laid down standards, which however, in itself needs reform. The Governing Council of the Colleges of Education is not doing enough as regard the standards and compliaince to standards of education in these schools. As earlier mentioned, some schools appoint lecturers who have no teaching qualifications and experience. Some lecturers in the Colleges of Education are the product of sandwich degree programme. It is absurd! The sandwich programme is not established to produce lecturers for higher institutions but for the in-service staff who may not have time to attend direct university education (Okpaga, 2016). Many of these graduates of the sandwich programme are not fit for the educating student in tertiary institutions. They lack adequate Pedagogical Content Knowledge (PCK) and low self-efficacy. There is the need to address these problems if there is going to be genuine reform.

The Nigeria University Commission (NUC) is doing its best to ensure a good university education, but there is unreported compromise sometimes as regard standard. The NUC had published the names of unaccredited universities sometimes ago, but those assumed qualified rearely keeps to standard as obtainnable in civilsed nations of the world. Academic research in many Nigerian universities is like a child's play. Most universities award Ph.D. degrees to unmerited candidates because of pecuniary benefits and familiarity. Some lecturers are so corrupt that, unless students give them money, they would not attend to the student's project or thesis. The careless attitude of some lecturers has made some student suffer setbacks due to students' missing thesis file in custody of their supervisors. Shortcoming like these does not occur in advanced countries and some African countries. All these will be unheardof we strict compliance to educational standards are in place and strictly enforced.

The National Commission for Colleges of Education (NCCE), assumes all Colleges of Education in Nigeria are qualified. Let us consider, a state which has three Colleges of Education that are poorly funded, yet the same state government would approve several other private colleges in the state. Most of these colleges have no standard classrooms, qualified lecturers, and other learning resources. They turned it into a business venture collecting huge school fees from the students and paying lecturers peanut as salaries. Outcomes of students from these ill-schools are found as teachers in our nations primary and secondary school levels today. This paragraph therefore, summarizes that both the NUC and NCCE also need critical reforms.

The school curriculum is another critical issue in Nigeria education. Several research studies indicate that the curricula are no longer relevant to the teaching of the present century. It is atypical for pupils to be learning on the bare floor without furniture and in some cases learning under the tree for lack of classroom building. The learning 
environment should form part of a school curriculum. The UNESCO (2012) has it that the principles of good learning environment, working approaches, as well as the concept of learning, should be in the core curriculum. Currently, our nations curriculum promotes base learning that is good for nothing but memorization. Education will not be able to solve the problem of a society where learning by memorization is practiced. Practical and comprehensive learning through activities and technological applications can. For the present and the future generations of learners and their teachers, the emergence of technology holds promise for addressing learning styles (McCoy \& Mathur, 2017, p.3). Thus, Sani (2012) had asserted that the tailoring of curricula content towards the critical needs of the society is essential.

Nonetheless, due of the highlighted problems above, the issue of quality assurance came up in the Nigerian education system. The initiation of the Quality Assurance by the Common Wealth of Learning (CWL) has its problem in Nigeria (Okonkwo \& Udeze, 2012) that requires reform. Corruption has undermined the Quality Assurance processes, and it cannot perform its function. The role of the Quality Assurance is to ensure and maintain a high standard of education at all levels; to assist in monitoring and supervision of education, and to determine the quality of teachers' input. The Quality Assurance processes in Nigerian education also needs also reform.

In the light of the preceding, the desirable education reform in Nigeria should be one that enhances sustainable development. To achieve a sustainable development, the demand for quality education must be met. Eilks and Burmeister (2013) observed that the German political debate concurs that education plays a crucial role in achieving sustainability, but they rarely implement practices that focus on education for sustainable development.

Therefore, this reform should focus the three-tier of education: primary, secondary and higher education. However, for the success of the reform, it must be noted that good governance and a zero-corruption tolerance society are a panacea for sustainable reform.

Good governance and a society devoid of corruption are inevitable for any reform in education for sustainable development. Good governance and quality education bring sustainable development for a nation (Amanchukwu, 2011). It is only good governance that can produce quality education for a country. Amanchukwu highlighted the feature of quality education as content relevance, access and outcome, and the observance of individual rights. Due to the absence of good governance, the school curricula are replete with contents not relevant to the need of the society and the learners. Many children of school age do not have access to education, and the outcome is insecurity, arm robbery, political thuggery and other vices witnessed in the country today. The political leaders do not believe in the right of any individual and thus permit personal ambitions, ethnic, and regional as well as religious persuasions to override national considerations (Odo, 2015).

It is quite worrisome that there has not been an adequate plan for a corresponding growth in population as regard to the educational system in Nigeria due to bad governance. According to Cordelia (1997), the unplanned and uncontrolled population growth in the educational system had created the crisis in the system as it is today. Cordelia highlighted the plight among other things such as inadequate funding, inadequate facilities, certificates racketeering and exam malpractices. Supporting this, Odia and Omofonmwan (2007) argued that the problem of education in Nigeria is insufficient funding, inadequate educational infrastructure, inadequate classrooms and polluted learning environment. 
Governance is one of the major problems in Africa (Otaghile, Igbafe, \& Agbontaen, 2014) which is the root cause of high rate of corruption in Nigeria. Corruption according to Ogundiya (2010) is an aspect of poor governance that is the abuse of public office for private gain. Corruption is everywhere, and it has crippled the nation education services and infrastructures. The heads of various academic institutions are corrupt. The Governing Councils of schools are also corrupt. These people do not value quality education, hence they can checkmate corrupt lecturers who turn lecturing into a money-making venture. Corruption destroys the civil-service which is the heart of modern development (Florence, Osawe, \& Igbokwe-Ibeto, 2015). There is a declining in the quality of education due to the administrative lapses vis-à-vis educational supervision and inspection (Arong \& Ogbadu, 2010).

There is mismanagement of the funds allocated for the construction of classrooms by the heads and the Governing Council of schools in collaboration with contractors. The result of this is the shortages of classroom spaces leading to teaching and learning in the open air (Moja, 2002). It also affects the teachers as they are unprepared for their role due to the absence of physical, educational facilities. The teacher thus has a low morale due to poor essential services such as work environment, lack of payment of salaries and allowances.

Some college management often diverts money meant for the teacher's welfare to attend academic conferences and seminars which are personal gains (Aina, Gana, \& Ibitomi, 2017). Sometimes unqualified people are given the opportunity to attend such meetings. This underscores the submission of Adeosun (2012) that the problem of nepotism makes leaders give privileges and undue advantages to their family members, friends, and associates, in the distribution of public resources.

Given this, good governance and society of zero tolerance for corruption would be a conducive environment in which the education reform suggested below could survive. Several attempts had been made and failed in the past for education reform because of governance and corruption. Therefore, believing the campaign of the present administration against corruption will work for the nation, the paper proposed the education reform below.

\section{PROPOSED EDUCATION REFORMS FOR NIGERIA}

The teacher is crucial to the success of any education system. Aaronson, Barrow, and Sander (2007); Rockoff (2004) noted that the teacher is significant to the students' academic achievement. The quality of education system of a nation depends to a great extent on the quality of teachers regarding academic and professional qualifications, experience, competency and their dedication to the primary functions (Oluremi, 2013). The success of any teaching and learning process which influence students' academic performance depends on the effectiveness and how qualified the teachers are (Sabitu \& Nuradeen, 2010). Teachers are the most critical variable in the effectiveness of schools and the quality of education of a child (Akinsolu, 2010).

Graduates of all teacher preparation programme require and should receive further support in professional preparation after graduation (Mynes \& Hatt, 2012). Base on this submission and the vital role of teachers in schooling, the followings are suggested as ways of reform for the Nigerian teachers:

Every graduate teacher should undergo an induction course for 3-6 months besides teaching practice and be certificated, just as graduates in law attends law schools, and medical students attends a year compulsory training. The establishment of the Teacher Registration Council of Nigeria (TRCN) is good but has not been effective. During this 
period, they will be required to concentrate on the pedagogy and the ethics of the teaching profession. It must be made compulsory for anyone who will teach in Nigerian schools. Here are some of the fundamental issues to be addressed during the period of induction.

a. The importance and need of training and re-training under an effective professional supervision.

b. The need to shift focus from teaching to students' learning. Most teachers believed in teaching very well with a good method which is good, but the students' learning and receptivity should be the focus not mainly how well the lesson was prepared.

There are specific characteristics of effective teaching practice by Mynes and Hatt (2012) that all teachers during the period of induction should inculcate which are

I. Pedagogical content knowledge (PCK), Passion and enthusiasm for the content

II. Ability to read the body language of the learners and

III. Carrying out classroom management strategies

For the teacher to be useful as it is in Finland, there should be an improved teachers' condition of service. There should be a committee to work out the best term of service for the Nigerian teachers as it is in the most advanced nations of the world. The condition of service should include living wages that will make teaching profession a prestigious one. The teaching profession is competitive in Finland. Research studies indicate that young Finnish prefer teaching to any other job because of its prestige (Simola, 2005). The conditions of service must be legislated to ensure the term is for all categories of teachers both public and private.

There should be standards for the three levels in Nigeria education system that must be strictly enforecd by both these public and the private institutions. The standard is to ensure that the Nigeria education focuses on high quality at all levels. In ensuring high quality in in Nigerian educational system, the eliminating of out-field teaching should be considered. Out-of-field is teachers teaching out of their field of qualification and/or specilaization. This might teachers to their areas of expertise such as a specific subject or year level (Du Plessis, 2013; Ingersoll, 2002). Teachers in the primary and secondary schools must teach only the they are certificated to teach. The pre-service teachers must also be trained for specific levels as it is in the industrialized world. In the US and Finland, there are teachers trained for the Kingdagateen and other grades; these teachers teach only at these level. The primary school teachers must be subject specific (Kola, 2007). In most of the primary schools in Nigeria, a teachers teaches all the subjects in his or her class. For instance, a teacher may be a Classmaster of two or three classes; the same teacher may be seen teaching mathematics, English language, agricultural science, social studies, religious knowledge, physical and health education and basic science. However, this teacher is a graduate of social studies, yet he or she teaches all subjects. It should not be, like this, and it needs correction in the reform.

Community Learning Education (CLE) is crucial today for holistic development of a child. The CLE in Singapore and Finland was essential to their school systems. Lee (2012) stated that the benefits of engaging educated and enthusiastic Singapore parents in supporting their children's learning outside schools could not be underrated. 
According to Sahlberg (2010), the Finnish teachers did not only teach but devoted time to the improvement of classroom practice, the school as a whole and work with the community. It should be mandatory for teachers to collaborate with learners' parents and members of the community from time to time for learning purpose. The reason is that parent plays a crucial and active role in facilitating children's learning outside the formal classrooms (Lee, 2012). This is not the Parent Teachers Association (PTA) as we presently have in Nigeria. There are more opportunities for children learning through informal learning outside the classroom settings (Crowley \& Galco, 2001).

Reform in Nigerian higher education is equally important because the sector has been marred by corruption. The first thing is to set up unifying standards for higher education in the country. There should be standards for establishing a new institution, student's admission, the students' management, financial management, the award of degrees, and many others. These measures should be for both the public and private schools and compliance most be strictly enforced and continually monitored.

The tuition fees of some state institutions are so high that only a few privileged students could afford. Lecturers in most of these public institutions are frequently on strike due to unpaid salaries and allowances. These schools make selection admission processes very easy to attract more students. There are no considerable learning resources in these schools, if any, maybe obsolete. The federal institutions charge various types of fees to exploit the students. The fees in the private schools are so high that only the children of the very rich and politicians can afford such. The reform should categorize and classify schools based on their learning facilities and stipulate their fees accordingly. Violation of payment according to this classification should be sanctioned by the regulatory bodies.

The federal ministry of education should constitute a research body to collaborate with the various regulatory agencies (NUC, NCCE, and other) to monitor students' project and thesis in the different institutions. The body should control and set the standard, quality and time duration of these theses. A Ph.D. programme should not exceed a maximum of five years while a Master programme should not exceed three years. There could be a Student-Lecturer Research alert system to check the abuse of project/thesis supervision.

The nation should strengthen the Public-Private Partnerships in Education (PPPE). This could help to solve the problem of underfunding of higher education in the country (Onuma, 2017). In many countries of the world, the presence of Public-Private Partnership (PPP) is apparent by the quality of research output in these universities. Private organizations who are NGOs participate in funding education and helping to improve the quality of education, especially increasing efficiency and reducing corruption. According to Aina and Akintunde (2015), Public-Private Partnerships in Education (PPPE) is a relationship in which the public (government) and private resources are voluntarily put together mainly for achieving educational goals. For instance, students and lecturers in most South African Universities enjoy research grants, Fellowships, Scholarships, and bursary through various private organizations and NGOs. The education reform should work ways to make PPP more functional in the Nigerian educational system. Perhaps, the reason PPPE has not been functioning well in Nigeria is due to the government unfaithfulness resulting from financial detour and corruption.

The government must give adequate attention to the education system, as done health, agriculture and other sectors. The appointment of Minister and Commissioners for the ministries of health and judiciary is by appointing experts in health and law respectively. However, for education, it is almost a position anybody. The educational sector 
is more crucial than any industrial sector in any nation as it responsible for training the workforce upon which every other sector and industry is built, sustained and secured. The appointment of "Mr. Anybody" as the Minister or Commissioner for education is tantamount to putting a 'round peg in a square hole.' Education deals with lives in of the people both in the present and future generations, it must thus be handled by someone who is an expert in the field of Education. The problem of Education is not a regulatory one: there are technical issues that could be managed only by the professionals. It is therefore recommended as a reform that the position of Minister and Commissioners of Education be appointed to seasoned experts and professionals in education.

The government should be more concerned about the laws guiding the individuals and the private organizations establishing private schools. The proliferation of schools with poor infrastructure, teaching and learning resources should be discouraged. The government should review its laws on the establishment of school by individuals and private organizations.

Finally, the present school curricula are teacher-dependent and need to be reformed and made less teacher focused and more students' focused activities at all level. To make schooling relevant to the students' need, requires the teacher to play the role of coaching and scaffolding. This will enable the teacher to always accommodate the needs of every individual in the class (Kame'enui, Carnine, Simmons, \& Coyne, 2002). The learning outcome must reflect how to apply acquired knowledge to solving real-life problems. Learning within a realistic classroom situation provides a useful real-life context for students and compares favourably to their views of the alternative pedagogical methods they frequently encounter at university (Herrington \& Oliver, 2000, p.35). The students' activity that is welldefined; promote exploration where students find as well as solve problems; and allow sustained thinking by exploring topics in an in-depth manner. (Herrington, 1997). The curricula should be reformed to allow for students' collaboration, expert modeling, articulation of understanding, providing multiple roles and perspective and cognitive reflection (Herrington, Reeves \& Oliver, 2010; Katz \& Lesgold, 1993; Kuhn, 2010).

\section{CONCLUSION}

The paper argued that reform in education is essential and imperative in the Nigeria education system as being done both in the developed and developing nations. However, the article faulted the reform in the Kaduna education system due to some fundamental issues highlighted in the paper. The reform must be holistic and not atomistic as the case of Kaduna state teachers' competency test now portrays. The paper emphasized the importance of teachers in any education system and offered some suggestions on how to make the Nigerian teachers vibrant in the profession. It also suggests that the Nigerian school curricula be reform to give the students more authentic learning activities. The paper, however, hinted that the reform might fail to produce quality education for sustainable development unless there is good governance and a society free of corruption. 


\section{REFERENCES}

Aaronson, D., Barrow, L., \& Sander, W. (2007). Teachers and student achievement in the Chicago Public Schools. Journal of Labour Economics 25, 95-135.

Adeosun, A.B. (2012). Nigeria@50: The role of good governance and effective public administration towards achieving economic growth and stability in fledgling democracy. International Journal of Politics and Good Governance, 3(3.3), 1-17.

Aina, J.K., Gana, N.N. and Ibitomi, O.O. (2017). The lack of good governance in Nigeria and its impact on functional science education. International Journal of Development and Sustainability, 6(9), 1036-1047

Aina, J.K., and Akintunde, Z.T. (2013). Repositioning science education in Nigerian colleges of education through Public-Private Partnership (PPP). Science Journal of Education, 1(5): 64-67. doi: 10.11648/j.sjedu.20130105.13

Akinbote, O. (2007) Problems of teacher education for primary schools in Nigeria: beyond curriculum design and implementation. Essays in Education, 22, 4-11.

Akindutire, I.O., and Ekundayo, H.T. (2012). Teacher education in a democratic Nigeria: Challenges and the way forward. Educational Research, 3(5), 429-435.

Akinsolu, A.O. (2010). Teachers and students' academic performance in Nigerian secondary schools: implications for planning. Florida Journal of Educational Administration and Policy, 3(2), 86-103.

Amanchukwu, R.N. (2011). The challenge of quality education and good governance in developing economy. African Journal of Education and Technology, 1(3), 103-110

Arong, F.E., and Ogbadu, M.A. (2010). Major causes of declining quality of education in Nigeria from administrative perspective: A case study of Dekina Local Government Area. Canadian Social Science, 6(3), $183-198$

Boyd, D., Landford, H., Loeb, S., Rockoff, J., and Wyckoff, J. (2008). The narrowing gap in New York City teacher qualifications and its implications for student achievement in high-poverty schools. Journal of Policy Analysis and Management, 27(4), 793-818.

Burmeister, M., and Eilks, I. (2013). An understanding of sustainability and education for sustainable development among German student teachers and trainee teachers of chemistry. Science Education International, 24(2), 167-194.

Brenneman, K. (2014). The progress of education reform: Science in the Early Years. Education Commission of the States, 15(2), 1-6.

Christie, K. (2014). The progress of education reform: Effectiveness-focused teacher preparation. Education Commission of the States, 15(5), 1-11.

Cordelia, C.N. (1997). The environment of crises in the Nigerian education system Comparative Education, $33(1), 87-95$

Crowley, K. and Galco, J. (2001). Everyday activity and the development of scientific thinking. In K. Crowley, 
C. D. Schunn \& T. Okada (Eds.), Designing for science: Implications from every day, classroom, and professional settings. Mahwah, NJ: Erlbaum.

Darling-Hammond, L. (2000). Teacher quality and student achievement: A review of state policy evidence.

Education Policy Analysis Archives, 8(1),1-44.

Darling-Hammond, L. (2010). Evaluating Teacher Effectiveness: How Teacher Performance Assessments Can

Measure and Improve Teaching. Retrieved April 28, 2018, from https://files.eric.ed.gov/fulltext/ED535859.pdf

Du Plessis, D.E. (2013). Understanding the out-of-field teaching experience. (Doctoral dissertation, The

$\begin{array}{lllll}\text { University of } & \text { Queensland, } & \text { Australia). }\end{array}$ https://espace.library.uq.edu.au/view/UQ:330372/s4245616_phd_submission

Du Plessis, A.E., Gillies, R.M., and Carroll, A. (2013). Out-of-field teaching and professional development: A transnational investigation across Australia and South Africa. International Journal of Educational Research, 66, 90-102.

Flippo, R. F., and Foster, C.R. (1984). Teacher competency testing and its impact on educators. Journal of Teacher Education, 35(2), 10-13

Florence, A.C., Osawe, O.C., and Igbokwe-Ibeto, C.J. (2015). The civil service and democratic governance in Nigeria: issues, prospects and new hopes. Journal of Research and Development (RnD), 2(8), 1-13.

Herrington, J.A. (1997). Authentic learning in interactive multimedia environments (Doctoral dissertation, Edith Cowan University, Australia). Retrieved from http://ro.ecu.edu.au/theses/1478

Herrington, J., Reeves, T. C. and Oliver, R. (2010). A guide to authentic e-learning. New York: Routledge Idakwoji, S.N. (2016). Issues of the teacher and improved educational achievement in Nigeria Schools.

Educational Research Journal, 6(2), 49-57

Ingersoll, R.M. (2000). Out-of-field teaching, educational inequality, and the organization of schools: An exploratory analysis. Centre for the Study of Teaching and Policy, University of Washington. Retrieved April 28, 2018, from http//www.cpre.org/sites/default/files/researchreport/796_outoffield-ri-01-2002.pdf

Kame'enui, E. J., Carnine, D.W., Dixon, R.C., Simmons, D.C., and Coyne, M.D. (2002). Effective teaching strategies that accommodate diverse learners $\left(2^{\text {nd }}\right.$ ed). Upper Saddle River, NJ: Merrill Prentice Hall.

Katz, S., and Lesgold, A. (1993). The role of the tutor in computer-based collaborative learning situations. In S.P. Lajoie and S.J. Derry (Eds.), Computers as cognitive tools (pp. 289-317). Hillsdale, NJ: Lawrence Erlbaum.

Kola, A.J (2007). Uses of instructional materials for teaching and learning physics in Edu and Patigi local government areas, Nigeria. International Journal of Research in Education. 4(1\&2), 74-79.

Kuhn, D. (2010). Teaching and learning science as argument. Science Education, 94(5), 810-824. doi: 10.1002/sce.20395.

Lee, A.N. (2012). Development of a parent's guide for the Singapore primary science curriculum: Empowering parents as facilitators of their children's science learning outside the formal classrooms. Asia-Pacific Forum on Science Learning and Teaching, 13(2), 1-27 
Libman, Z. (2012). Licensing procedures, teacher effectiveness and reasonable expectations. International Review of Education, 58, 151-171. doi: 10.1007/s11159-012-9275-7

Maynes, N. (2012). Shifting the focus to student learning: Characteristics of effective teaching practice as identified by experienced pre-service faculty advisors. Brock Education, 22(1), 93-110

McCoy, Km.M., \& Mathur, S.R. (2017). Differentiation in the digital-based classroom: A universal design approach for inclusive setting in middle schools. Journal of Education and Development, 1(1), 1-11

Moja, T. (2000). Nigeria education sector analysis: An analytical synthesis of performance and main issues. Retrieved from https://www.researchgate.net/publication/237751253

Mynes, N., \& Hatt, B.E. (2012). Shifting the focus to student learning: characteristics of effective teaching practice as identified by experienced pre-service faculty advisors. Brock Education, 22(1), 93-110

Nasser, R et al. (2014). Alignment of teacher-developed curricula and national standards in Qatar's national education reform. International Education Studies, 7(10), 14-24

National Commission for Colleges of Education [NCCE] (2008). The national minimum standard for Nigeria Certificate in Education ( $4^{\text {th }}$ Ed). Kaduna: Author.

Odia, L., O., and Omofonmwan, S. I. (2007). Educational system in Nigeria problems and prospects. Journal of Social Science, 14(1), 81-86.

Odo, L.U. (2015). Democracy and good governance in Nigeria: Challenges and prospects. Global Journal of HumanSocial Science (F). 15(3), 1-9.

Ogundiya, I.S. (2010). Democracy and good governance: Nigeria's dilemma. African Journal of Political Science and International Relations, 4(6) 201-208.

Okemakinde, T, Alabi, C.O, and Adewuyi, J.O. (2013). The place of teacher in national development in Nigeria. European Journal of Humanities and Social Sciences, 19(1), 963-980.

Okonkwo, V.O., and Udeze, H.E. (2012). Quality assurance in teacher's education in Nigeria: Challenges and the way forward. Journal of Research and Development, 4(1), 127-134.

Oluremi, O.F. (2013). Enhancing educational effectiveness in Nigeria through teacher's professional development. European Scientific Journal, 9(28), 422-431.

Omosewo, E. S. (2008). Physics teacher education and national education reforms. In A.R. Lawal, A. J. Shehu, S. A. Olorundare, N.Y. S. Ijaiya (Eds.), Education Reforms in Nigeria, Past, Present and Future. Nigeria, Ibadan: Sterling-Horden Publishers Ltd.

Onuma, N. (2017). Under-funding tertiary education in Nigeria: implication for sustainable national development. IRA International Journal of Education and Multidisciplinary Studies 7(3), 174-183. doi: http://dx.doi.org/10.21013/jems.v7.n3.p1

Okpaga, A. (2016). Distance learning, sandwich and open education system in Nigeria: challenges and prospects for educational development. International Journal of Academia, 1(1), 343-352

Otoghile A., Igbafe, A.A., and Aghontaen, E.S. (2014). The quest for good governance in Nigeria: A survey of people's perception in Benin City. Research on Humanities and Social Sciences, 4(28), 179-188.

Palardy, G.J., and Rumberger, R.W. (2008). Teacher effectiveness in first grade: The importance of background 
qualifications, attitudes, and instructional practices for student learning, Educational Evaluation and Policy Analysis, 30 (2), 111-140.

Rockoff, J. (2004). The impact of individual teachers on student achievement: Evidence from panel data. American Economic Review, 94, 247-252.

Sabitu, A.O, and Nuradeen, B.B (2010). Teachers' attitudes as correlates of students' academic performance in geography in secondary schools in Ondo state, Nigeria. Pakistan Journal of Social Sciences, 7(5), 388-392.

Sahlberg, P. (2010). The secret to Finland's success: Educating teachers. Stanford Centre for Opportunity Policy in Education-Research brief.

Sani, A. (2014). Nigerian curriculum and national integration: Issues and challenges. British Journal of Education, Society \& Behavioural Science, 4(3), 309-317.

Sawari, S.S.B. (2013). Teacher competency assessment in the classroom: Current issues. International Journal of Informative and Futuristic Research (IJIFR), 1(3), 90-96.

Semola, T (2010). Who is joining physics and why? Factors influencing the choice of Physics among Ethiopian University students. International Journal of Environmental and Science Education, 5(3), 319-340.

Srivastava, S., and Srivastava, P.K. (2017). Need to restructure teacher education in India with reference to globalization and localization. IRA-International Journal of Education \& Multidisciplinary Studies, 7(2), 73-78

Steiner, L. (2010). Using Competency-Based Evaluation to Drive Teacher Excellence: Lessons from Singapore. Building an Opportunity Culture for America's Teachers. Retrieved April 28, 2018, from http:// www.opportunityculture.org.

United Nations Educational, Scientific and Cultural Organization [UNESCO] (2012). Education for sustainable development in action. Paris: Author

Zinth J.D. (2014). The progress of education reform- Career and technical education: States aligning programs to meet workforce needs education Commission of the States, 15(2), 1-7.

Zuzovsky, R. (2009). Teachers' qualifications and their impact on student achievement: Findings from TIMSS 2003 data for Israel. Retrieved April 29, 2018 from http://www.ierinstitute.org/IERI 